Jurnal Akuntansi dan Manajemen

Vol.11, No. 2, 2016, Hal. 76-92

\title{
Pengaruh Intellectual Capital Terhadap Kinerja Keuangan Perusahaan \\ (Studi pada Perusahaan Farmasi yang Terdaftar di Bursa Efek Indonesia Periode 2010-2014)
}

\author{
Nia Mawarsih \\ Jurusan Akuntansi, Politeknik Negeri Padang \\ Email:nia.mawarsih@gmail.com
}

\begin{abstract}
Abstact
This study aims to determine the effect of intellectual capital on the company's financial performance. The independent variable used in this study is intellectual capital. The dependent variable used in this study is the company's financial performance as measured by Return on Assets (ROA). Return on Equity (ROE) and Growth of Revenue (GR). The research sample is a pharmaceutical company that is listed on the Indonesia Stock Exchange (IDX) with a study period of 2010-2014. Data was collected by purposive sampling method, based on these criteria, as many as 8 companies were selected as samples in this study. The analysis technique used is simple linear regression analysis using SPSS v.20 software. the test shows that (1) intellectual capital has an effect on ROA, (2) intellectual capital has an effect on ROE (3) intellectual capital does not affect GR.
\end{abstract}

Keywords: Intellectual capital, Return on Assets (ROA), Return on Equity (ROE), Growth of Revenue (GR).

\begin{abstract}
Abstrak
Penelitian ini bertujuan untuk mengetahui pengaruh intellectual capital terhadap kinerja keuangan perusahaan. Variabel independen yang digunakan dalam penelitian ini adalah intellectual capital. Variabel dependen yang digunakan dalam penelitian ini adalah kinerja keuangan perusahaan yang diukur dengan Return on Asset (ROA). Return on Equity (ROE) dan Growth of Revenue (GR). Sampel penelitian ini perusahaan farmasi yang terdaftar di Bursa Efek Indonesia (BEI) dengan periode penelitian tahun 2010-2014. Data dikumpulkan dengan metode purposive sampling, berdasarkan kriteria tersebut maka sebanyak 8 perusahaan terpilih sebagai sampel dalam penelitian ini. Teknik analisa yang digunakan adalah analisi regresi linear sederhana menggunakan software SPSS v.20. hal pengujian menunjukkan bahwa (1) intellectual capital berpengaruh terhadap ROA, (2) intellectual capital berpengaruh terhadap ROE (3) intellectual capital tidak berpengaruh terhadap GR.

Kata kunci: Intellectual capital, Return on Asset (ROA), Return on Equity (ROE), Growth of Revenue (GR)

\section{Pendahuluan}

Dalam pengembangan sebuah usaha, perusahaan membutuhkan aset yang cukup untuk menjalankan usahanya. Aset yang dimiliki perusahaan dalam beroperasi/menjalankan aktivitasnya tidak hanya aset berwujud (tangible asset)
\end{abstract}


namun perusahaan juga membutuhkan aset tidak berwujud (intangible asset). Aset tidak berwujud adalah aset nonmoneter yang dapat diidentifikasi tanpa substansi fisik (IAI, 2009). Sumber daya tidak berwujud adalah kunci untuk menciptakan dan mempertahankan keunggulan kompetitif serta merupakan dasar untuk sukses di abad kedua puluh (Ghosh, 2009).

Salah satu aset tidak berwujud yang paling berpengaruh dalam kemajuan dan keberhasilan sebuah perusahaan adalah intellectual capital. Intellectual capital adalah materi intelektual (pengetahuan, informasi, intelektual, pengalaman) yang dapat digunakan untuk menciptakan kekayaan, dengan kata lain materi intelektual merupakan suatu kekuatan akan kolektif atau seperangkat pengetahuan yang berdaya guna (Stewart, 1997 dalam Astuti, 2004). Stewart (1997) dalam Ghosh (2009) menjelaskan istilah intellectual capital sebagai "intellectual material" pengetahuan, informasi, "intellectual property", pengalaman yang dapat menjadi hasil akhir dari proses transfomasi pengetahuan dan pengetahuan yang ditransformasikan menjadi "intellectual property". Pada umumnya intellectual capital dikelompokkan menjadi tiga komponen, yaitu human capital, structural capital dan relational capital. Human capital meliputi pengetahuan, keahlian, kompetansi dan motivasi yang dimiliki karyawan. Structural capital mencakup budaya perusahaan, komputer software, dan teknologi informasi. Sedangkan relational capital meliputi loyalitas konsumen, pelayanan jasa terhadap konsumen, dan hubungan baik dengan pemasok. Pengakuan dan penerapan intellectual capital merupakan prasyarat untuk keberhasilan organisasi dalam lingkungan yang kompetitif (Wang et all. 2011).

Penelitian mengenai intellectual capital menarik karena intellectual capital merupakan salah satu aset yang vital bagi perusahaan, karena memiliki manfaat untuk meningkatkan kinerja perusahaan dan menciptakan nilai perusahaan sehingga akan mencapai keunggulan kompetitif (Yuniasih, dkk. 2010). Perusahaan yang mampu mengelola intellectual capital yang dimilikinya dengan efektif dan efisien, maka kinerja keuangannya akan meningkat. Kinerja keuangan yang meningkat akan direspon positif oleh pasar sehingga nilai perusahaan akan meningkat.

Kinerja keuangan perusahaan dalam penelitian ini diukur menggunakan Return on Asset (ROA), Return on Equity (ROE) dan Growth of Revenue (GR). ROA adalah rasio yang digunakan untuk mengukur tingkat pengembalian total aset. merupakan rasio antara laba sesudah pajak terhadap total aset. Semakin besar ROA menunjukkan kinerja perusahaan semakin baik, karena tingkat kembalian (return) semakin besar (Ang, 1997 dalam Azwir 2006). ROE mengukur tingkat profitabilitas perusahaan dengan menghitung berapa banyak jumlah keuntungan perusahaan yang dihasilkan dari dana yang diinvestasikan oleh para pemegang saham. ROE akan dilihat oleh investor sebagai salah satu rasio keuangan yang penting dalam pengambilan keputusan investasi. Peneliti menggunakan ROE untuk mengetahui tingkat efisiensi perusahaan dalam menghasilkan profit dari setiap dana yang diinvestasikan oleh pemegang saham. Sedangkan Growth of Revenue (GR) mengukur perubahan pendapatan sebuah perusahaan. Peningkatan dalam pendapatan merupakan sinyal bahwa perusahaan mempunyai kesempatan untuk tumbuh (Harniek 2009).

Ghosh et all. (2009) menganalisis hubungan antara intellectual capital dan ukuran kinerja keuangan konvensional perusahaan perangkat lunak dan farmasi di India. Hasil analisis menunjukkan bahwa hubungan intellectual capital dan indikator kinerja 
konvensional (profitabilitas, produktivitas dan nilai pasar) bervariasi. Temuan menunjukkan bahwa intellectual capital perusahaan dapat menjelaskan profitabilitas tetapi tidak produktivitas dan nilai pasar di India.

Sharabati et all. (2010) menguji secara empiris hubungan antara intellectual capital (human capital, structural capital, relational capital) dan kinerja perusahaan dalam sektor farmasi di Jordan. Hasil menunjukkan bahwa tiga sub-konstruksi intellectual capital (human capital, structural capital, relational capital) bersama sama memiliki hubungan positif dengan kinerja perusahaan.

Firer dan Williams (2003) dalam Ulum (2008) menguji hubungan VAIC $^{\text {тM }}$ dengan kinerja perusahaan di Afrika Selatan. Hasilnya mengindikasikan hubungan antara efisiensi dari value added intellectual capital dan tiga dasar ukuran kinerja perusahaan (profitability, productivity, dan market valuation) secara umum adalah terbatas. Secara keseluruhan, hasil penelitian ini menunjukkan bahwa phisical capital merupakan faktor yang paling berpengaruh terhadap kinerja perusahaan di Afrika Selatan.

Penelitian yang penulis lakukan menggunakan tiga indikator penelitian sebagaimana yang dilakukan oleh Chen et all. (2005) yaitu Return On Assets (ROA), Return On Equity (ROE), dan Growth in Revenue (GR) dengan objek penelitian yang berbeda yaitu industri farmasi di Indonesia. Penelitian ini memilih perusahaanperusahaan farmasi yang listing di Bursa Efek Indonesia sebagai objek kajian. Perusahaan farmasi dipilih sebagai objek kajian karena menurut Sharabati et all. (2010) perusahaan farmasi merupakan industri yang sangat memanfaatkan intellectual capital. Industri farmasi adalah industri yang padat modal karena sejumlah besar investasi diperlukan untuk penemuan dan produksi obat baru. Industri farmasi juga memiliki fitur pengetahuan industri dasar karena pekerjaan yang terampil, prosedur yang unik, dan penyelidikan ilmiah sangat diperlukan untuk produksi dan penjualan (Amin, 2014). Berdasarkan Surat Keputusan Menteri Kesehatan Nomor 245/MenKes/SK/V/1990 tentang Ketentuan dan Tata Cara Pelaksanaan Pemberian Izin Usaha Industri Farmasi, menjelaskan bahwa industri farmasi adalah industri obat jadi dan industri bahan baku obat. Definisi dari obat jadi adalah sediaan atau paduan bahan-bahan yang siap digunakan untuk mempengaruhi atau menyelidiki sistem fisiologi atau keadaan patologi dalam rangka penetapan diagnosa, pencegahan, penyembuhan, pemulihan, peningkatan kesehatan dan kontrasepsi. Dalam menciptakan obat jadi, dibutuhkan paduan-paduan yang tepat untuk menciptakan obat yang benar-benar berkhasiat serta tidak memiliki efek samping yang berbahaya. Oleh karena itu dibutuhkan keterampilan, kecerdasan, dan pengetahuan yang lebih untuk terus berinovasi dalam menciptakan sebuah produk. Industri farmasi memiliki ketergantungannya yang luas pada intellectual capital sebagai sumber utama inovasi (Mehralian et all. 2012). Menurut Data Kementerian Kesehatan 2013, jumlah perusahaan farmasi di Indonesia mencapai 206 perusahaan. Rata-rata penjualan obat ditingkat nasional selalu tumbuh 12\%-13\% setiap tahun dan bila dilihat secara global, perusahaan farmasi merupakan perusahaan yang memiliki pasar yang besar. Penjualan industri farmasi seluruh dunia pada tahun 2005 sebesar US\$ 534,8 Milyar dan pada tahun 2010 diramalkan penjualan produk farmasi akan mencapai US\$ 767,2 Milyar (Kamath, 2008). Hal ini menandakan perusahaan farmasi merupakan industri yang besar dan terus berkembang. Intellectual capital dalam 
industri farmasi merupakan kebutuhan utama karena tuntutan untuk terus berinovasi dalam menciptakan produk untuk kebutuhan konsumen serta bersaing dengan perusahaan lain.

Penelitian ini berusaha untuk meneliti pengaruh intellectual capital terhadap kinerja keuangan perusahaan farmasi yang terdaftar di Bursa Efek Indonesia (BEI) periode tahun 2012-2014 dengan metode Pulic (1998) yaitu Value Added Intellectual Coefficient (VAICTM). Pada penelitian sebelumnya yang dilakukan oleh Chen et all. (2005) kinerja keuangan perusahaan diukur dengan Return on Equity (ROE), Return on Total Assets (ROA), Growth in Revenue (GR). Peneliti memilih sektor farmasi sebagai sampel dalam penelitian ini karena sektor farmasi merupakan sektor industri yang dinilai sangat intensif akan pengetahuan dan merupakan sumber yang besar akan intellectual capital (Daum, 2005).

\section{Landasan Teori}

\section{Intellectual Capital}

Intellectual capital sangat berperan penting dalam perusahaan, terlebih pada perusahaan farmasi yang bergerak dalam bidang pembuatan obat-obatan yang menjadi modal utama untuk bekerja dibidang ini adalah kecerdasan intelektualnya, yang akan menjadi daya saing dengan perusahan lainnya. Brooking (tahun) dalam Ulum (2008) mendefinisikan intellectual capital sebagai berikut: "intellectual capital is the term given to the combined intangible assets of market, intellectual property, human centred and infrastructure-which enable the company to function". Roos et all. (tahun) dalam Ulum (2008) menyatakan bahwa: "intellectual capital includes all the processes and the assets which are not normally shown on the balance-sheet and all the intangible assets (trademarks, patent and brands) which modern accounting methods consider...". Stewart (tahun) dalam Ulum (2008) menyebutkan bahwa: "intellectual capital is intellectual material-knowledge, information, intellectual property, experience that can be put to use to create wealth". Sedangkan Bontis (tahun) dalam Ulum (2008) mengakui bahwa: "intellectual capital is exclusive, but once it is discovered and exploited, it may provide an organisation with a new resource-base from which to compete and win".

Komponen Intellectual Capital menurut Stewart (1998), Sveiby (1997), Saint-Onge (1996) dan Bontis (2000) dalam Suwarjuno (2003) menyatakan bahwa intellectual capital terdiri dari tiga elemen utama, diantaranya yaitu:

a. Human Capital (Modal Manusia)

b. Structural Capital atau Organizational Capital (Modal Organisasi)

c. Relational Capital atau Costumer Capital (Modal Pelanggan)

\section{Resource Based Theory}

Teori ini beranggapan bahwa perusahaan akan mampu mencapai keunggulan yang kompetitif apabila memiliki sumber daya yang unggul pula. Resource based theory merupakan suatu pemikiran yang berkembang dalam manajemen strategik dan keunggulan kompetiti perusahaan yang menganalisis dan menginterpretasikan sumber daya organisasi untuk memahami bagaimana organisasi mencapai keunggulan kompetitif berkelanjutan. Resource based theory dipelopori oleh Penrose (1959) dalam Astuti (2005), mengemukakan bahwa sumber daya perusahaan adalah 
heterogen, tidak homogen, jasa produktif yang tersedia berasal dari sumber daya perusahaan yang memberikan karakter unik bagi tiap-tiap perusahaan.

Ketika perusahaan memiliki sumber daya yang unggul, perusahaan dapat menciptakan dan menerapkan berbagai strategi bisnis dengan baik dan benar. Hasil dari pengelolaan sumber daya dengan baik dan benar adalah perusahaan dapat menciptakan value added yang akan berpengaruh terhadap kinerja perusahaan dan pertumbuhan perusahaan, serta nilai pasar perusahaan tersebut.

\section{Perhitungan Intellectual Capital dengan VAICTM}

Value Added Intellectual Capital (VAIC), yaitu dengan melihat kemampuan intelektual yang dimiliki oleh perusahaan tersebut dan nilai yang dimiliki perusahaan tersebut hingga saat ini. Ulum (2008) mengembangkan metode VAIC yang didesain untuk menyajikan informasi tentang value creation efficiency dari aset berwujud (tangible asset) dan aset tidak berwujud (intangible asset) yang dimiliki perusahaan. Model ini dimulai dengan kemampuan perusahaan menciptakan value added (VA). Value Added dihitung sebagai selisih antara output dan input. Teori ini beranggapan bahwa perusahaan akan mampu mencapai keunggulan yang kompetitif apabila memiliki sumber daya yang unggul pula.

\section{Return On Asset (ROA)}

Hanafi dan Halim (2005) menyatakan bahwa analisis ROA mengukur kemampuan perusahaan menghasilkan laba dengan menggunakan total asset (kekayaan) yang dipunyai perusahaan setelah disesuaikan dengan biaya-biaya untuk mendanai asset tersebut. ROA bisa diinterprestasikan sebagai hasil dari serangkaian kebijakan perusahaan (strategi) dan pengaruh dari factor-faktor lingkungan (environmental factors). Analisis difokuskan pada profitabilitas aset, dan dengan demikian tidak memperhitungkan cara-cara untuk mendanai aset tersebut. Rasio ini menunjukkan tingkat efisiensi pengelolaan aktiva yang dilakukan oleh perusahaan. Semakin besar return on asset maka semakin besar tingkat keuntungan dan semakin baik posisi perusahaan dari segi penggunaan aktiva.

Hal yang berperan terhadap besar kecilnya return on asset adalah perputaran dari jumlah dana yang ditanam dalam perusahaan, yakni jumlah hasil penjualan dibandingkan jumlah dana yang ditanam. Rasio laba atas dana operasi dihitung sebagai berikut:

Keterangan : EAT = Earning After Tax

$$
\text { Return on Assets = EAT / Total Assets X } 100 \%
$$

\section{Return On Equity (ROE)}

Return on equity adalah jumlah laba bersih yang dikembalikan sebagai persentase dari ekuitas pemegang saham. Return on equity mengukur tingkat profitabilitas perusahaan dengan menghitung berapa banyak jumlah keuntungan perusahaan yang dihasilkan dari dana yang diinvestasikan oleh para pemegang saham. Return on equity dilihat oleh investor sebagai salah satu rasio keuangan yang penting. Return on equity mengukur efisiensi perusahaan dalam menghasilkan profit dari setiap uang yang 
diinvestasikan oleh pemegang saham pada suatu entitas. Perhitungannya adalah dengan membagi laba bersih dengan jumlah ekuitas stakeholder.

ROE $=($ Laba Bersih Setelah Pajak / Total Modal Pemegang Saham $) \times 100 \%$

\section{Growth Revenue (GR)}

Growth revenue digunakan untuk mengukur seberapa cepat perusahaan berkembang. Growth revenue menunjukkan tingkat kenaikan atau penurunan pendapatan perusahaan atau pertumbuhan penjualan. Dengan demikian investor mendapat gambaran tentang berapa banyak pendapatan perusahaan meningkat dari tahun ke tahun. Peningkatan pendapatan perusahaan menunjukkan bahwa perusahaan dapat mengelola intellectual capital-nya dengan baik.

GR: [(Pendapatan tahun t / Pendapatan tahun t-1) -1] x 100\%

\section{Kerangka Berpikir}

Kerangka berpikir penelitian ini dapat digambarkan sebagai berikut:

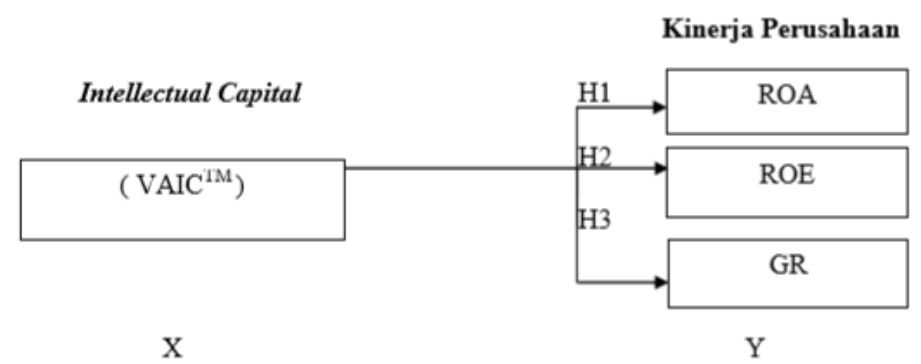

Keterangan: VAIC: Mengukur kemampuan intelektual perusahaan ROA: Mengukur kemampuan perusahaan menghasilkan laba dengan menggunakan total aset perusahaan ROE: Mengukur kemampuan perusahaan menghasilkan laba dengan dana yang diinvestasikan oleh para pemegang saham GR : Mengukur seberapa cepat perusahaan berkembang

\section{Pengembangan Hipotesis}

H1: Intellectual capital (VAICTM) berpengaruh terhadap Return on Assets (ROA)

H2: Intellectual capital (VAICTM) berpengaruh terhadap Return on Equity (ROE)

H3: Intellectual capital (VAICTM) berpengaruh terhadap growth in revenue (GR)

\section{Metodologi Penelitian}

Desain Penelitian, Penelitian ini merupakan penelitian kuantitatif dengan hipotesis yang bertujuan untuk menguji pengaruh intellectual capital terhadap profitabilitas pada industri farmasi yang terdaftar di Bursa Efek Indonesia periode 2010-2014. Penelitian ini menggunakan dua variabel, antara lain variabel independen yaitu intellectual capital dan variabel dependen yaitu kinerja keuangan (lampiran 2). Kinerja keuangan dalam penelitian ini menggunakan rasio return on asset, return on equity, serta rasio pertumbuhan pendapatan atau growth of revenue. berikut:

Definisi dari variabel yang digunakan serta pengukurannya adalah sebagai a. Intellectual Capital (IC) adalah hasil dari jumlah 3 komponen utama organisasi (human capital, structural capital dan customer capital) yang berhubungan dengan 
pengetahuan yang dimiliki sumber daya manusia serta teknologi yang memberikan kontribusi terhadap kemampuan perusahaan dalam bersaing dengan perusahaan lainnya. Intellectual capital diukur dengan menggunakan metode VAICTM yang dikemukakan oleh Pulic (1998). VAICTM dapat dihitung sebagai berikut:

1. Tahap pertama : Menghitung Value Added (VA)

Value added dihitung sebagai selisih antara output dan input Pulic (1998)

OUT - IN = VA

Keterangan: Out = Output: total penjualan dan pendapatan lain, $I n=$ Input: Keseluruhan beban yang dikeluarkan untuk perusahaan kecuali beban karyawan (lampiran 3).

2. Tahap kedua : Menghitung Value Added Capital Employee

VACA adalah indikator untuk VA yang diciptakan oleh satu unit dari physical capital. Rasio ini menunjukan kontribusi yang dibuat oleh setiap unit dari CE terhadap value added organisasi.

$$
\mathrm{VACA}=\mathrm{VA} / \mathrm{CE}
$$

Keterangan: VACA $=$ value added capital employee $:$ rasio dari VA terhadap, CE $\mathrm{VA}=$ value added $\mathrm{CE}=$ capital employee: dana yang tersedia yaitu total ekuitas perusahaan, laba bersih setelah pajak (lampiran 3)

3. Tahap ketiga: Menghitung Value Added Human Capital (VAHU)

VAHU menunjukan berapa banyak VA dapat dihasilkan dengan dana yang dikeluarkan untuk tenaga kerja. Rasio ini menunjukan kontribusi yang dibuat oleh setiap rupiah yang diinvestasikan dalam HC terhadap value added organisasi.

$$
\mathrm{VAHU}=\mathrm{VA} / \mathrm{HC}
$$

Keterangan: VAHU = Value Added Human Capital: rasio dari VA terhadap HC, VA = Value added HC = Human Capital : keseluruhan beban yang dikeluarkan perusahaan untuk karyawannya. Contohnya yaitu beban gaji, tunjangan, upah, pelatihan, jaminan sosial, kesejahteraan karyawan, dan biaya imbalan kerja (lampiran 3)

4. Tahap keempat: Menghitung Structural Capital Value Added (STVA)

Rasio ini menghitung jumlah SC yang dibutuhkan untuk menghasilkan 1 rupiah dari VA dan merupakan indikasi bagaimana keberhasilan SC dalam penciptaan nilai.

$$
\text { STVA }=\text { SC } / \text { VA }
$$

Keterangan: STVA $=$ Structural capital value added $:$ rasio dari SC terhadap VA SC = Structural capital: $\mathrm{VA}-\mathrm{HC}$ VA = Value added

5. Tahap kelima: Menghitung Value Added Intellectual Coefficient (VAICTM) VAICTM mengindikasikan kemampuan intelektual organisasi yang dapat juga dianggap sebagai BPI (Bussiness Performance Indikator). VAICTM merupakan penjumlahan dari tiga komponen sebelumnya, yaitu: VACA, VAHU dan STVA.

$$
\text { VAICTM = VACA + VAHU + STVA }
$$


b. Kinerja keuangan perusahaan dapat dilihat dari profitabilitas yang dihasilkan perusahaan. Profitabilitas adalah kemampuan perusahaan dalam menghasilkan keuntungan dari kegiatan bisnis yang dilakukan perusahaan dibandingkan dengan penjualannya, investasi asset dan ekuitasnya (Gitman, 2009 dalam Wijaya 2012).

1. ROA (return on asset) adalah rasio yang digunakan untuk mengukur tingkat pengembalian total asset. Rasionya adalah :

$$
\text { ROA }=\text { EAT / Total Asset x } 100 \%
$$

\section{Return on Equity ( $R O E$ )}

ROE mengukur tingkat profitabilitas perusahaan dengan menghitung berapa banyak jumlah keuntungan perusahaan yang dihasilkan dari dana yang diinvestasikan oleh para pemegang saham.

$$
\text { ROE }=(\text { EAT } / \text { Total Modal Pemegang Saham }) \times 100 \%
$$

Keterangan: EAT = Laba bersih setelah pajak

\section{Growth of Revenue (GR)}

Growth revenue digunakan untuk mengukur seberapa cepat perusahaan berkembang. Growth revenue menunjukkan tingkat kenaikan atau penurunan pendapatan perusahaan atau pertumbuhan penjualan. Peningkatan pendapatan biasanya merupakan peluang bagi perusahaan untuk menigkatkan pertumbuhan pendapatan (Chen et all. 2005).

GR: [(Pendapatan tahun t / Pendapatan tahun t-1) -1] x 100\%

Data yang digunakan dalam penelitian ini adalah data sekunder. Data penelitian berupa laporan keuangan tahunan perusahaan farmasi yang terdaftar di Bursa Efek Indonesia tahun 2010-2014 sebanyak 10 perusahaan. Dalam penelitian ini data sekunder diperoleh dengan cara melakukan dokumentasi terhadap laporan keuangan perusahaan yang telah go public dan listed di Bursa Efek Indonesia. Data diperoleh dari situs Bursa Efek Indonesia www.idx.co.id. Penelitian ini menggunakan metode purposive sampling, dengan kriteria sebagai berikut:

a. Perusahaan menerbitkan laporan tahunan selama periode 2010 2014,

b. Laporan keuangan perusahaan untuk tahun yang berakhir pada tanggal 31 Desember,

c. Laporan tahunan dapat diakses melalui website perusahaan,

d. Perusahaan memiliki data yang terkait dengan variabel dalam penelitian ini

Metode Analasis Data menggunakan Statistik deskriptif memberikan gambaran atau deskripsi suatu data yang dilihat dari nilai rata-rata (mean), standar deviasi, maksimum, minimum (Ghozali, 2006) sedangkan Pengujian Hipotesis menggunakan Analisis regresi merupakan suatu alat ukur yang dapat digunakan untuk mengukur ada tidaknya korelasi antar variabel dan untuk menunjukkan arah hubungan antara variabel independen dan variabel dependen.

\section{Hasil Penelitian Dan Pembahasan}

Adapun hasil dan pembahasan dari penelitian ini adalah sebagai berikut:

1. Statistik Deskriptif 
Analisis deskriptif digunakan untuk memberikan gambaran atau deskripsi atas variabel-variabel penelitian. Pengukuran yang digunakan dalam penelitian ini adalah mean, standar deviasi, nilai minimum, dan nilai maximum. Tabel 4.3 (lampiran 4) menunjukan statistik deskriptif masing-masing variabel penelitian.

Tabel 4.3

Descriptive Statistics

\begin{tabular}{|l|r|r|r|r|r|}
\hline & N & Minimum & Maximum & Mean & $\begin{array}{c}\text { Std. } \\
\text { Deviation }\end{array}$ \\
\hline VAIC & 40 & 2.0261 & 10.1081 & 5.421788 & 2.3411595 \\
ROA & 40 & .0009 & .3956 & .140730 & .0980183 \\
ROE & 40 & .0020 & .4678 & .185849 & .1150182 \\
GR & 40 & -.2727 & .2664 & .079402 & .0927353 \\
Valid N & 40 & & & & \\
(listwise) & & & & \\
\hline
\end{tabular}

2. Hasil Uji Normalitas

Ghozali (2006) menyatakan bahwa uji normalitas adalah untuk menguji apakah model regresi, variabel independen, dan variabel dependennya memiliki distribusi data normal atau tidak. Model regresi yang baik adalah memiliki distribusi data normal atau mendekati normal. Uji normalitas dilakukan dengan uji kolmogorov-smirnov satu arah atau analisis grafis. Hasil uji normalitas menggunakan kolmogorov-smirnov untuk variabel dependen penelitian dapat dilihat pada tabel 4.4 (lampiran 4).

Tabel 4.4

\section{Hasil Uji Normalitas}

\begin{tabular}{|l|l|l|}
\hline $\begin{array}{l}\text { Variabel } \\
\text { Dependent }\end{array}$ & $\begin{array}{l}\text { Kolmogorov-Smirnov } \\
\text { Z }\end{array}$ & $\begin{array}{l}\text { Asymp. Sig. (2- } \\
\text { tailed) }\end{array}$ \\
\hline ROA & 0.737 & 0.649 \\
\hline ROE & 0.870 & 0.436 \\
\hline GR & 0.870 & 0.435 \\
\hline $\begin{array}{l}\text { a. Independent variable : VAIC } \\
\text { b. Test distribution is normal } \\
\text { c. Calculated from data }\end{array}$ \\
\hline
\end{tabular}

Sumber : Data sekunder yang diolah, 2015 (lampiran 4)

3. Hasil Uji Autokorelasi

Uji autokorelasi digunakan untuk menguji apakah dalam model regresi linear terdapat korelasi antara kesalahan pengganggu pada periode $t$ dengan kesalahan pengganggu pada periode t-1 (sebelumnya). Model regresi yang baik adalah regresi yang bebas dari autokorelasi. Untuk mendeteksi ada tidaknya autokorelasi penelitian ini menggunakan metode uji Durbin-Watson (DW test). Nilai angka dl dan du diambil dari Durbin-Watson Test. Sesuai sampel yang ada dalam penelitian ini yaitu $\mathrm{n}=40$ dan $\mathrm{k}$ (variabel independen) $=3$ dengan 
significance $=0,05$. Maka didapat angka dl =1,4421 dan du=1,5444. Tabel 4.5 (lampiran 1) menunjukan hasil uji autokorelasi.

Tabel 4.5

Hasil Uji Autokorelasi

\begin{tabular}{|l|c|r|r|r|l|}
\hline Model & R & $\begin{array}{c}\text { R } \\
\text { Square }\end{array}$ & $\begin{array}{c}\text { Adjusted R } \\
\text { Square }\end{array}$ & $\begin{array}{c}\text { Std. Error of } \\
\text { the Estimate }\end{array}$ & $\begin{array}{c}\text { Durbin- } \\
\text { Watson }\end{array}$ \\
\hline ROA & $.579^{\mathrm{a}}$ & .335 & .317 & .1032667 & 2.887 \\
\hline ROE & $.523^{\mathrm{a}}$ & .273 & .254 & .1000941 & 2.837 \\
\hline GR & $.114^{\mathrm{a}}$ & .013 & -.013 & .0934557 & 2.070 \\
\hline $\begin{array}{l}\text { a. Predictors: (Constant), VAIC } \\
\text { b. Dependent Variable: ROA, ROE, GR }\end{array}$
\end{tabular}

Sumber : Data sekunder yang diolah, 2015 (lampiran 4)

4. Hasil Pengujian Heteroskedastisitas

Uji Heteroskedastisitas bertujuan untuk menguji apakah dalam model regresi terjadi ketidaksamaan varians dari residual satu pengamatan ke pengamatan yang lain. Pengujian heteroskedastisitas pada penelitian ini menggunakan diagram titik (scatter plot) yang seharusnya titik-titik tersebut tersebar acak agar tidak terdapat heteroskeditas. Hasil uji heteroskeditas dalam penelitian ini disajikan pada gambar 4.4, gambar 4.5 dan 4.6 berikut ini (lampiran 4).

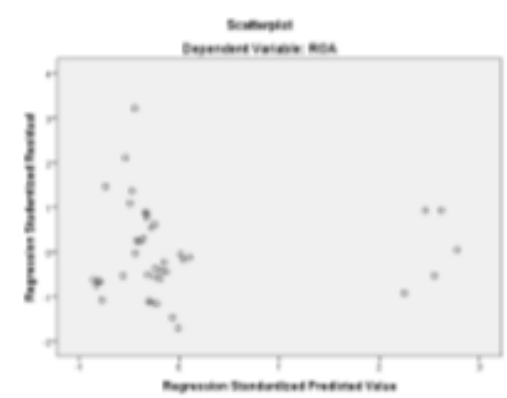

Sumber : Data sekunder yang diolah, 2015

Gambar 4.4

Diagram Scatter Plot 


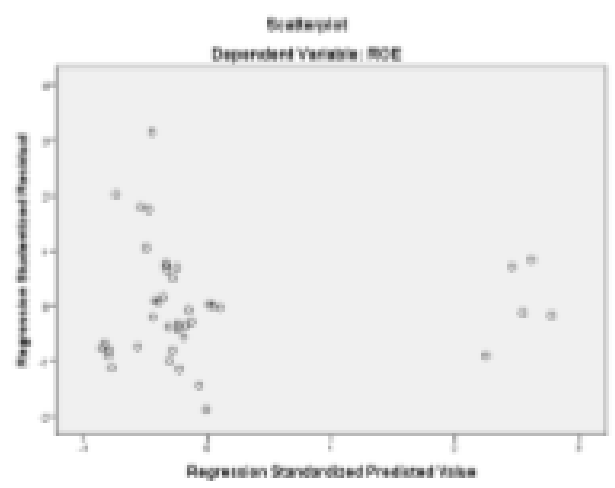

Sumber : Data sekunder yang diolah, 2015

Gambar 4.5

Diagram Scatter Plot

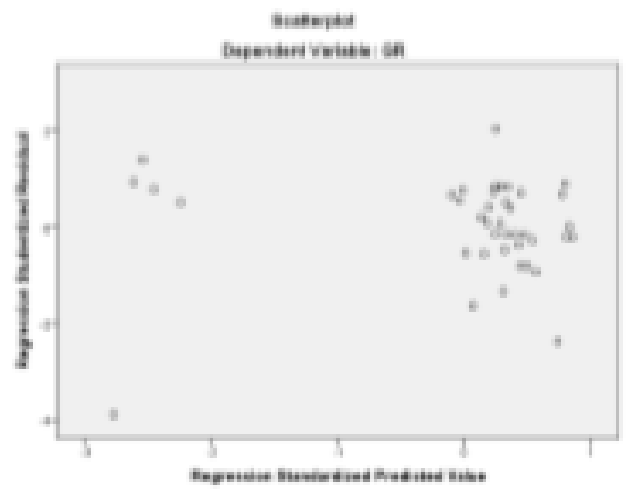

Sumber : Data sekunder yang diolah, 2015

\section{Gambar 4.6}

\section{Diagram Scatter Plot}

Pembahasan

1. Analisis Regresi Linear Sederhana

Analisis regresi linear sederhana adalah hubungan seara linear antara satu variabel independen (X) dengan variabel dependen (Y). Analisis ini bertujuan untuk memprediksi nilai dari variabel dependen apabila nilai variabel independen mengalami kenaikan atau penurunan dan untuk mengetahui arah hubungan antara variabel independen dengan variabel dependen apakah positif atau negatif.

a. Koefisien Determinasi (Adjusted R2)

Adjusted R-Squared digunakan untuk mengetahui sejauh mana kemampuan variable variabel independen dalam menjelaskan variabel dependen. Nilai R2 
yang kecil berarti kemampuan variabel-variabel independen dalam menjelaskan variabel dependen, terbatas. Sebaliknya, nilai R2 yang mendekati satu menandakan variabel-variabel independen memberikan hampir semua informasi yang dibutuhkan oleh variabel dependen (Ghozali, 2005). Hasil koefisien determinan dapat terlihat pada tabel 4.6 (lampiran 4).

Tabel 4.6

Koefisien Determinasi

\begin{tabular}{|l|l|r|r|l|l|}
\hline Model & Var. Dep & R & R Square & $\begin{array}{l}\text { Adjusted R } \\
\text { Square }\end{array}$ & $\begin{array}{l}\text { Std. Error } \\
\text { of the } \\
\text { Estimate }\end{array}$ \\
\hline 1 & ROA & $.579^{4}$ & .335 & .317 & .1032667 \\
\hline 2 & ROE & $.523^{4}$ & .273 & .254 & .1000941 \\
\hline 3 & GR & $.114^{\mathrm{a}}$ & .013 & -.013 & .0934557 \\
\hline
\end{tabular}

Untuk model 1 besarnya nilai Adjusted R Square adalah sebesar 0,317 yang berarti variabel independen mampu menunjukkan perubahan dari ROA hanya sebesar 31,7\% dan sisanya sebesar 68,3\% dijelaskan oleh faktor di luar model. Pada model 2, nilai R Square adalah 0,254 yang berarti variabel independen mampu menunjukkan perubahan dari ROE hanya sebesar 25,4\%. Sedangkan pada model 3 nilai R Square adalah sebesar $-0,013$. Nilai adjusted R2 yang negatif dianggap bernilai nol (Gujarati 2003) . Ini menjelaskan bahwa model ini tidak bagus sehingga nilai GR tidak dapat dijelaskan oleh variabel independen yaitu VAIC. Hal ini diperkirakan karena terdapat beberapa perusahaan sampel penelitian yang memiliki nilai Growth of Revenue (GR) negatif atau tidak adanya pertumbuhan pendapatan pada perusahaan sampel tersebut.

b. Uji t

Pengujian t dilakukan untuk mengetahui pengaruh variabel independen secara individu (parsial) terhadap variabel dependen dengan menganggap variabel independen yang lain konstan. Pengujian ini dilakukan dengan membandingkan nilai signifikansi t yang ditunjukkan oleh Sig dari t pada tabel 4.7 dengan tingkat signifikansi yang diambil, dalam hal ini 0,05 . Jika nilai Sig. dari $t<0,05$ maka variabel independen berpengaruh terhadap variable dependen. Hasil uji t dapat dilihat pada tabel 4.7 (lampiran 4) berikut: 
Table 4.7

Hasil Uji t

\begin{tabular}{|c|c|c|c|c|c|c|}
\hline \multirow[b]{2}{*}{ Model } & \multirow[b]{2}{*}{ Var. Dep } & & \multicolumn{2}{|c|}{ Unstandardized Coefficients } & \multirow[b]{2}{*}{$\mathbf{t}$} & \multirow[b]{2}{*}{ Sig. } \\
\hline & & & B & $\begin{array}{l}\text { Std. } \\
\text { Error }\end{array}$ & & \\
\hline \multirow[t]{2}{*}{1} & ROA & (Constant) & .089 & .027 & 3.281 & .002 \\
\hline & & VAIC & .008 & .002 & 4.373 & .000 \\
\hline \multirow[t]{2}{*}{2} & ROE & (Constant) & .107 & .026 & 4.046 & .000 \\
\hline & & VAIC & .006 & .002 & 3.781 & .001 \\
\hline \multirow[t]{2}{*}{3} & GR & (Constant) & .094 & .025 & 3.810 & .000 \\
\hline & & VAIC & -.001 & .002 & -.710 & .482 \\
\hline
\end{tabular}

Tabel 4.7 memaparkan hasil regresi linier terhadap model 1, 2, dan 3 untuk menguji ketiga hipotesis dalam penelitian ini yaitu membuktikan bahwa VAIC berpengaruh terhadap kinerja keuangan yang diproksikan dengan ROA, ROE tetapi VAIC tidak berpengaruh terhadap GR.

1. Pengaruh Intellectual Capital terhadap Return on Asset (ROA)

Model 1: $\mathrm{ROA}=0.089+0.008 \mathrm{VAIC}$

Hasil pengujian hipotesis mengenai pengaruh variabel intellectual capital (VAIC) terhadap return on asset (ROA) menunjukkan nilai signifikansi sebesar 0,000 $(\mathrm{p}<0,05)$ yang berarti bahwa $\mathrm{H} 1$ diterima sehingga dapat dikatakan bahwa intellectual capital berpengaruh terhadap return on asset (ROA). Dari persamaan regresi model 1 dapat terlihat nilai konstanta $(\alpha)$ adalah sebesar 0.089 artinya apabila variabel bebas (VAIC) konstan, maka diprediksikan return on asset pada perusahaan farmasi yang terdaftar di Bursa Efek Indonesia periode 2010-2014 adalah sebesar 0.089. Nilai yang positif pada koefisien regresi menunjukkan hubungan searah antara variabel independen dengan variabel dependennya. Hal ini berarti jika terjadi kenaikan VAIC sebesar 1 maka akan menaikkan nilai Return On Assets (ROA) sebesar 0,08 \%. Intellectual capital dalam penelitian ini diukur dengan metode VAICTM. Dengan demikian, H1 diterima. Hasil penelitian ini konsisten dengan penelitian Chen et all (2005) dan Ghosh \& Mondal (2009) yang membuktikan bahwa apabila penggunaan dan pemanfaatan intellectual capital semakin baik, maka kinerja perusahaan akan semakin baik pula. Oleh karena itu, kemampuan perusahaan dalam menghasilkan laba dengan total asset yang dimiliki akan semakin meningkat apabila perusahaan dapat memanfaatkan intellectual capital yang dimiliki dengan baik.

2. Pengaruh Intellectual Capital terhadap Return on Equity (ROE)

Model 2: $\mathrm{ROE}=0.107+0.006$ VAIC

Hasil lain dari penelitian ini membuktikan bahwa VAIC memiliki pengaruh terhadap ROE. Hal ini tampak dari tingkat signifikan sebesar 0,001 ( $\mathrm{p}<0,05)$ yang berarti bahwa VAIC berpengaruh terhadap ROE. Dengan demikian H2 diterima. Dari persamaan regresi model 2, nilai konstanta sebesar 0,107 menyatakan bahwa return on equity (ROE) pada perusahaan farmasi yang 
terdaftar di Bursa Efek Indonesia periode 2010-2014 adalah sebesar 0,107. Koefisien regresi pada variabel ROE adalah sebesar 0,006 . Tanda positif pada koefisien regresi menunjukkan hubungan searah antara variabel independen dengan variabel dependennya. Hal ini berarti kenaikan VAIC sebesar 1 akan menaikan nilai return on equity (ROE) sebesar $0.06 \%$.

Berpengaruhnya Intellectual Capital terhadap ROE dapat disebabkan karena modal yang diperoleh oleh investor lebih banyak digunakan untuk mendanai kegiatan operasional perusahaan. Hal ini berarti pada saat perusahaan dapat memanfaatkan modal yang dimiliki secara maksimal, para investor akan merespon hal tersebut secara positif yang ditunjukkan dengan meningkatnya kinerja perusahaan. Selain itu, di kemudian hari investor memiliki kecenderungan untuk berinvestasi pada perusahaan yang memiliki nilai VAIC yang tinggi, karena semakin besar VAIC yang dimiliki perusahaan, maka semakin besar pula pengelolaan sumber daya yang dapat digunakan perusahaan dan dengan demikian semakin besar pula return yang dapat diharapkan dari perusahaan atas investasinya. Pengaruh VAIC terhadap ROE sejalan dengan hasil penelitian Ulum (2008) dan Wijaya (2012). Hasil penelitian ini membuktikan bahwa masing-masing sumber daya yang dimiliki perusahaan digunakan dengan efisien dan efektif sehingga meningkatkan laba perusahaan yang mengakibatkan kinerja keuangan yang diukur dengan ROE meningkat.

\section{Pengaruh Intellectual Capital terhadap Growth of Revenue (GR)}

Model 3: GR $=0.094-0.001$ VAIC

Kontribusi Intellectual Capital untuk sebuah kinerja perusahaan akan berbeda sesuai dengan jenis industrinya (Kuryanto, 2008). Penelitian ini membuktikan bahwa VAIC tidak memiliki pengaruh terhadap GR. Hal ini tampak dari tingkat signifikan sebesar $0.482(p>0,05)$ yang berarti bahwa VAIC tidak berpengaruh terhadap GR. Begitu pula terlihat pada table koefisien determinasi yang menunjukan nilai adjusted R2 sebesar -0.013 , nilai adjusted R2 yang negatif dianggap nol, sehingga VAIC tidak bisa menjelaskan variable GR. Hal tersebut kemungkinan dikarenakan beberapa perusahaan sampel memiliki nilai growth of revenue negatif, dan presentase growth of revenue yang negatif adalah sebesar $14 \%$ jika dibandingkan dengan kenaikan seluruh growth of revenue dari perusahaan sampel. Dikarenakan variabel X (VAIC) tidak berpengaruh terhadap variabel Y (GR), maka model regresi tersebut tidak bisa digunakan. Jika variabel $\mathrm{X}$ tidak berpengaruh maka seberapapun nilai $\mathrm{X}$ tersebut tidak akan mempengaruhi besar atau kecilnya nilai growth of revenue (GR). Dengan demikian Hipotesis 3 tidak dapat diterima. Hasil penelitian secara parsial konsisten dengan penelitian Etika (2012) dan Rambe (2012).

\section{Kesimpulan Dan Saran}

Penelitian ini menguji pengaruh Intellectual Capital terhadap kinerja perusahaan yang diukur dengan Return on Asset (ROA), Return on Equity (ROE) dan Growth of Revenue (GR). Intellectual capital pada penelitian ini diukur dengan menggunakan model Pulic-Value Added Intellectual Capital (VAICTM). Berdasarkan hasil pengujian statistik dan analisis yang telah dibahas pada bab sebelumnya, maka diperoleh 
kesimpulan sebagai berikut: 1. Intellectual capital (VAICTM) berpengaruh terhadap kinerja keuangan yang diukur dengan Return on Asset (ROA). Hal ini terlihat dari hasil uji $\mathrm{t}$ yang menunjukan nilai sig. untuk variabel ROA sebesar 0,000 tingkat signifikansi tersebut lebih lebih kecil dari 0,05 yang berarti $\mathrm{H} 1$ diterima sehingga dapat dikatakan bahwa secara parsial VAICTM berpengaruh terhadap ROA. 2 . Intellectual Capital (VAICTM) berpengaruh terhadap return on equity (ROE). Hal ini terlihat dari hasil uji t yang menunjukan nilai sig. Untuk variabel ROE sebesar 0,001 tingkat signifikansi tersebut lebih lebih kecil dari 0,05 yang berarti $\mathrm{H} 2$ diterima sehingga dapat dikatakan bahwa secara parsial VAICTM berpengaruh terhadap ROE. Hasil ini menunjukan bahwa Intellectual capital merupakan salah satu variabel penting yang menentukan kinerja keuangan terutama perusahaan farmasi di Indonesia. 3. Intellectual Capital (VAICTM) tidak berpengaruh terhadap Growth of Revenues (GR) . Hal ini terlihat dari hasil uji t yang menunjukan nilai sig. Sebesar 0,482 tingkat signifikansi tersebut lebih besar dari 0,05 yang berarti H3 tidak dapat diterima sehingga secara parsial VAICTM tidak berpengaruh terhadap GR. Hal ini mengindikasikan bahwa kemampuan perusahaan untuk tumbuh tidak dipengaruhi oleh Intellectual Capital yang diwujudkan dalam kemampuan perusahaan dalam mengelola aset keuangan, mengolah sumber daya manusianya ataupun struktur organisasinya.

Penelitian selanjutnya dapat mengukur intellectual capital dengan metode yang berbeda, mengingat metode yang dapat digunakan untuk mengukur nilai intellectual capital sudah mulai berkembang. Bagi peneliti selanjutnya dapat melakukan penambahan variabel lain dari variabel yang pernah diteliti sebelumnya. Perusahaan sebaiknya lebih memperhatikan indikator-indikator ideal untuk masing-masing komponen intellectual capital yang dapat meningkatkan kinerja keuangan perusahaan, seperti 1. Human capital harus lebih memperhatikan masalah kapabilias karyawan, kepuasan karyawan dan kreativitas karyawan, 2. Structural capital harus lebih memperhatikan masalah sistem informasi, proses organisasi dan budaya organisasi, serta 3. Relational capital harus lebih memperhatikan masalah kapabilitas dasar pemasaran, loyalitas pelanggan, intensitas pasar dan hubungan dengan masyarakat.

\section{Referensi}

Amin, Shahid. 2014. "Intellectual Capital and Financial Performance of Pharmaceutical Firms in Pakistan". Pakistan Journal of Social Sciences (PJSS) Vol. 34, No. 2 (2014), pp. 433-450, Pakistan

Astuti, Partiwi Dwi. 2005. "Hubungan Intellectual Capital dan Business Performance”. Tesis. Semarang: Magister Sains Akuntansi Universitas Diponegoro.

Azwir, Yacub. 2006. “Analisis Pengaruh Kecukupan Modal, Efisiensi, Likuiditas, Npl, Dan Ppap Terhadap Roa Bank". Tesis. Universitas Diponegoro, Semarang. Bursa Efek Indonesia. (2010-2014). Laporan Keuangan Auditan Perusahaan Farmasi yang Terdaftar di Bursa Efek Indonesia dari tahun 2010 sampai tahun 2014. Ditelusuri 27 Mei-4 Juni. http://www.idx.co.id/.

Chen, M.C., Cheng, S.J. dan Hwang, Y. 2005. "An Empirical Investigation of The Relationship Between Intellectual Capital and Firms' Market Value and Financial Performance". Journal of Intellectual Capital. 6 (2): 159-176 
Daum, J.H. (2005). "Intangible Assets-Based Enterprise Management: A Practical Approach". Proceeding of 2005 PMA IC Symposium, Stern School of Business, New York University, Manhattan, 15 December.

Entika, Nova Lili Dan M Didik Ardiyanto. 2012. “Pengaruh Elemen Pembentuk Intellectual Capital Terhadap Nilai Pasar Dan Kinerja Keuangan Pada Perusahaan Perbankan Yang Terdaftar Di Bursa Efek Indonesia (BEI)". Diponegoro Journal of Accounting. Vol. 1, No. 2.

Fatima, Hasna. 2012. “Analisis Pengaruh Modal Intelektual Terhadap Kinerja Perusahaan di Indonesia". Skripsi. Depok : Universitas Indonesia.

Ghazali, I. 2006. "Aplikasi Analisis Multivariate Dengan Program SPSS, Cetakan IV". Semarang: Badan Penerbit Universitas Diponegoro

Ghosh, S. and A. Mondal. (2009). "Indian Software and Pharmaceutical Sector IC and Financial Performance". Journal of IC, 10(3), 369-88.

Harniek, Diah. 2009. "Pengaruh Intellectual Capital terhadap Market Value dan Financial Performance pada Perusahaan Jasa Keuangan yang Terdaftar di Bursa Efek Indonesia". Skripsi. Universitas Airlangga. Surabaya.

Herdyanto, Ivan. 2013. "Pengaruh Intellectual Capital pada Financial Performance Perusahaan". Skripsi. Semarang: Universitas Diponegoro

Huang, C. and M-C., Wang. (2008). "The Effect of Economic Value Added and Intellectual Capital on the Market Value of the Firms: an Empirical Study". International Journal of Management, 25(3), 722-779.

Ikatan Akuntan Indonesia (IAI). 2009. Pernyataan Standar Akuntansi Keuangan (PSAK) No. 19: Aset Tidak Berwujud. Jakarta: Salemba Empat.

Kamath, G. Bharathi. 2008. "Intellectual Capital and Corporate Performance in Indian Pharmaceutical Industry". Journal of Intellectual Capital, Vol. 9, pp 684-704

Khoriah, Kiki. 2012. "Pengaruh Modal Intelektual Terhadap Kinerja Keuangan Perusahaan Serta Dampaknya Terhadap Harga Saham". Skripsi. Tasikmalaya: Universitas Indonesia.

Mamduh Hanafi, dan Abdul Halim. 2005. Analisis Laporan Keuangan. Edisi Kedua, Cetakan Pertama. Yogyakarta : YKPN.

Mehralian, G., Rajabzadeh, A., Sadeh, M. R. and H. R. Rasekh. (2012). "Intellectual Capital and Corporate Performance in Iranian Pharmaceutical Industry". Journal of Intellectual Capital, 13(1), 138-58.

Pulic, A. 1998. "Measuring the performance of intellectual potential in knowledge economy". McMaster World Congress on Measuring and Managing Intellectual Capital by the Austrian Team for Intellectual Potential.

Rambe, Rizki Fillhayati. 2012. "Pengaruh Intellectual Capital terhadap Perusahaan Perbankan yang Terdaftar di BEI". Jurnal Keuangan dan Bisnis, November 2012, Vol 4, No. 3.

Sawarjuwono, Tjiptohadi dan Agustine Prihatin Kadir, 2003. "Intellectual Capital: Perlakuan, Pengukuran dan Pelaporan (Sebuah Library Research)". Jurnal Akuntansi dan Keuangan, Mei 2003, Vol. 5, No. 1.

Sharabati et al. 2010. "Intellectual Capital and Business Performance In The Pharmaceutical Sector of Jordan". Journal of Intellectual Capital. Vol. 48 No. 1, 2010 pp. $105-131$ 
Tarigan, Timotius. 2011. "Analisis Pengaruh Intellectual Capital Terhadap Kinerja Perusahaan Sektor Farmasi Yang Terdaftar Di Bursa Efek Indonesia Tahun 20062010". Skripsi. Semarang: Universitas Diponegoro

Ulum, Ihyaul, 2008. "Intellectual Capital Performance Sektor Perbankan di Indonesia". Jurnal Akuntansi dan Keuangan, November 2008, Vol. 10, No. 2.

Wijaya, Novia. 2012. "Pegaruh Intellectual Capital Terhadap Kinerja Keuangan dan Nilai Pasar Perbankan Dengan Metode Value Added Intellectual Coefficient". Jurnal Bisnis dan Akuntansi, Desember 2012, Vol. 14, No. 3.

Wijaya, Sherly Putri. 2012. "Pengaruh Intellectual Capital terhadap Profitabilitas pada Perusahaan Farmasi Di BEI". Jurnal Ilmiah Mahasiswa Akuntansi, Mei 2012, Vol. 1, No. 3.

Yuniasih, N.,W., D.G. Wirama, dan I. D. N. Badera, 2010. "Eksplorasi Kinerja Pasar Perusahaan, Kajian Berdasarkan Modal Intelektual (Studi Empiris pada Perusahaan Keuangan yang Terdaftar di Bursa Efek Indonesia)". Simposium Nasional Akuntansi XIII, Purwokerto. 